\title{
cash4, a novel achaete-scute homolog induced by Hensen's node during generation of the posterior nervous system
}

\author{
Domingos Henrique, ${ }^{1}$ Dave Tyler, ${ }^{1}$ Chris Kintner, ${ }^{3}$ John K. Heath, ${ }^{4}$ Julian H. Lewis, ${ }^{2}$ \\ David Ish-Horowicz, ${ }^{1}$ and Kate G. Storey ${ }^{5,6}$ \\ ${ }^{1}$ Developmental Genetics and ${ }^{2}$ Organogenesis Laboratories, Imperial Cancer Research Fund, Lincoln's Inn Fields, London \\ WC2A 3PX, UK ${ }^{3}$ The Salk Institute for Biological Studies, San Diego, California, 92186 USA; ${ }^{4}$ Department of Biochemistry, \\ University of Birmingham, Edgbaston B15 2TT, UK; ${ }^{5}$ Department of Human Anatomy, University of Oxford, \\ Oxford OX1 3QX, UK
}

In vertebrate embryos, the precursor cells of the central nervous system (CNS) are induced by signaling from the organizer region. Here we report the isolation of a novel vertebrate achaete-scute homolog, cash4, which is expressed in the presumptive posterior nervous system in response to such signaling. cash 4 is first expressed in epiblast cells flanking the late-phase organizer (Hensen's node), which retains its ability to induce cash4 during regression to the caudal end of the embryo. We show that these node-derived signals can be mimicked in vivo by the activity of fibroblast growth factor (FGF). We demonstrate that cash4 can substitute for the achaete/scute genes in the fly and that it also has proneural activity in vertebrate embryos. Together these results suggest that cash 4 functions as a proneural gene downstream of node-derived signals (including FGF) to promote the formation of the neural precursors that will give rise to the posterior CNS in the chick embryo.

[Key Words: Neural induction; fibroblast growth factor; posterior nervous system; neurogenesis; achaete-scute; chick embryo]

Received November 13, 1996; revised version accepted January 22, 1997.

During vertebrate gastrulation, neural-inducing signals emanate from a unique region of the embryo, the organizer (Spemann and Mangold 1924; Waddington 1932; Beddington 1994). A number of neural-inducing molecules are expressed in the organizer and have activities that support Spemann's original observation that head and trunk regions of the nervous system are induced in two distinct phases (Spemann 1927; also see Nieuwkoop 1952; Saxén and Toivonen 1961; after Hamburger 1988). Initially, neural inducing molecules such as Noggin, Follistatin, and Chordin induce anterior neural tissue, in part by inhibiting the activity of the epidermal inducing factor BMP4 (Lamb et al. 1993; Hemmati-Brivanlou et al. 1994; Sasai et al. 1995; Piccolo et al. 1996; Zimmerman et al. 1996; also see Kengaku and Okamoto 1995; Streit et al. 1995). Later, signals such as fibroblast growth factor (FGF) and retinoic acid (RA) transform part of this neural tissue to a more posterior character (Maden and Holder 1992; Slack and Tannahill 1992; Cox and Hem-

${ }^{6}$ Corresponding author.

E-MAIL kstorey@ermine.ox.ac.uk; FAX 01865-272420.
mati-Brivanlou 1995; Kengaku and Okamoto 1995; Lamb and Harland 1995; Crossley et al. 1996).

How the newly induced neural tissue integrates these successive sets of signals and acquires its final identity is still poorly understood. However, recent characterization of vertebrate homologs of Drosophila genes that control neural specification in the fly has shed light on the molecular events that are initiated by neural inducing signals and serve to implement neural cell fates in vertebrate embryos. In Drosophila, neural precursors are established by a cascade of genes, at the top of which lies the Achaete-Scute Complex (ASC) (for review, see Campuzano and Modolell 1992; Ghysen and DamblyChaudière 1993; Jan and Jan 1994; Skeath and Carroll 1994). The four ASC genes [lethal-of-scute (1'sc), scute $(s c)$, achaete $(a c)$, and asense (ase)] encode basic helixloop-helix (bHLH) transcriptional regulators whose transient expression confers neural potential on groups of ectodermal cells (so-called proneural clusters). Subsequently, lateral inhibition, mediated by the activities of the neurogenic genes, restricts neural potential to a single cell in a cluster (for review, see Campos-Ortega 1993), which expresses higher levels of the ASC genes 
and will become a neuroblast, a founder cell of the fly nervous system. In embryos carrying mutations in the ASC genes, fewer neural precursors are formed, which leads to a reduction in the number of nerve cells in the central or peripheral nervous system (Dambly-Chaudière and Ghysen 1987; Ruiz-Gómez and Modolell 1987; Villares and Cabrera 1987; Jiménez and Campos-Ortega 1990|.

Vertebrate homologs of the ASC genes have been isolated and found to be expressed in the developing nervous system (Johnson et al. 1990; Ferreiro et al. 1992; Guillemot and Joyner 1993; Zimmerman et al. 1993; Jasoni et al. 1994). Mutations in one of these, mash1, result in the loss of particular classes of neuron in the olfactory and peripheral nervous system (Guillemot et al. 19931. However, mash1 is not expressed during the determination of neural precursors and is not required for their specification; instead, mash1 is present in terminally dividing neuronal progenitors to control subsequent differentiation (Guillemot et al. 1993; Gordon et al. 1995; Sommer et al. 1995). Another vertebrate ASC homolog, xash3, which has been isolated only in Xenopus embryos, is expressed in subsets of neural precursors shortly after neural induction and is a better candidate for acting as a proneural gene (Zimmerman et al. 1993; Ferreiro et al. 1994; Turner and Weintraub 1994). Overexpression of xash 3 mRNA in the frog embryo results in the expansion of the neural plate, because of the conversion of presumptive neural crest and epidermis to a neural plate character (Turner and Weintraub 1994; Chitnis and Kintner 1996), indicating that xash3 may promote the neural precursor state in a manner analogous to that of the ASC genes in the fly.

Another group of vertebrate genes encoding related bHLH proteins is expressed in the developing CNS and has homology with the Drosophila proneural gene atonal (Akazawa et al. 1995; Lee et al. 1995; Shimizu et al. 1995; Ma et al. 1996). One of these genes, neuroD, is expressed in postmitotic neurons and has been shown to drive neuronal differentiation when expressed ectopically in the amphibian embryo (Lee et al. 1995). Another atonal homolog, neurogenin (Ma et al. 1996), has an expression pattern in the developing mouse central nervous system (CNS) that is complementary to that of mash 1 and may thus have a similar function during neuronal differentiation. A related gene, ngnr-1, is expressed early during primary neurogenesis in Xenopus embryos and has been proposed to act as a neuronal determination gene (Ma et al. 1996). Ectopic ngnr-1 expression also promotes the formation of primary neurons and is able to induce the expression of neuroD, suggesting that ngnr-1 functions in the determination of neuronal progenitors during the genesis of the frog primary nervous system.

All these results point to the existence of a cascade of bHLH proteins acting during primary neurogenesis in the frog embryo, including early determination factors such as XASH3 and NGNR-1, and later differentiation factors like NeuroD, in a manner akin to the cascade of myogenic bHLH factors that operate during myogenesis (Weintraub 1993; Lee et al. 1995). However, none of the
bHLH-encoding genes already isolated in vertebrates are expressed early enough during CNS development to play a role in neural determination (specification of neural precursors that give rise to both neurons and glial as distinct from neuronal determination (specification of neuronal progenitors that give rise solely to neurons).

Here we report the isolation of a novel ASC gene homolog in the chick, cash 4 (chick achaete-scute homolog-4) whose early expression in neural precursors is initiated by signals from Hensen's node. We show that these signals persist in the node throughout the period during which the posterior CNS is laid down, and that this activity can be mimicked in vivo by a member of the FGF family. cash 4 can promote neural cell fates in vertebrate embryos and is a functional homolog of the fly ASC genes. These findings suggest that cash 4 functions as a proneural gene in the chick to specify precursor cells of the posterior CNS, and we show that this specification process takes place continuously in response to signals, including FGF, from the regressing node/anterior primitive streak.

\section{Results}

\section{Isolation of cash4 cDNA}

We have identified a novel ASC homolog, cash4, using PCR and degenerate oligonucleotide primers that correspond to sequences conserved between the fly ASC proteins and the three vertebrate ASC homologs isolated previously (Johnson et al. 1990; Guillemot and Joyner 1993; Zimmerman et al. 1993). The cash4 PCR fragment was used to isolate a $1.4-\mathrm{kb}$ cash $4 \mathrm{cDNA}$ that encodes a 167-amino-acid bHLH protein, related to the ASC family of proteins (Fig. 1A). These are characterized by the unique structure of their bHLH domain, with a basic region that differs from analogous motifs in other bHLH transcriptional regulators. In the case of CASH4, the basic region clearly resembles that of the Drosophila ASC proteins and is distinct from that of other classes of bHLH proteins (Fig. 1B). However, in common with vertebrate ASC proteins isolated previously, the loop region of the CASH4 bHLH domain is shorter than equivalent regions of the fly ASC proteins. CASH4 possesses two further conserved regions (Fig. 1A): a 15-amino-acid sequence just amino-terminal to the basic domain /region A), conserved between CASH4 and the vertebrate ASH1 and $\mathrm{ASH} 2$ proteins (less conserved in XASH3; Zimmerman et al. 1993), and another (region B, 25 amino acids) at the carboxyl terminus, which is almost identical in $\mathrm{CASH} 1$ and CASH4 but absent from the other two vertebrate homologs, MASH2 and XASH3. Both regions include serine residues that are potential sites of phosphorylation. CASH4 also contains proline and alaninerich regions amino-terminal to the bHLH domain that could function in transcriptional modulation.

\section{cash4 expression in the early chick embryo}

cash4-expressing cells in the early chick embryo were localized by whole-mount in situ hybridization using di- 


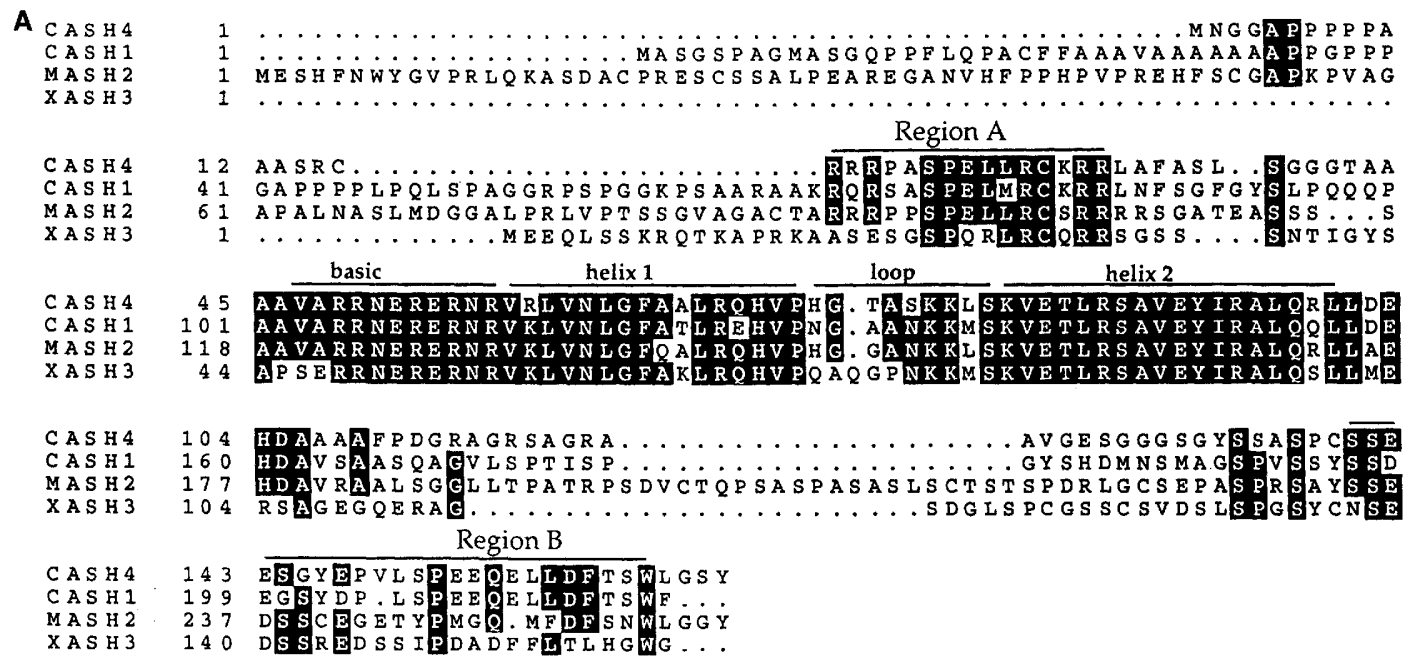

B

CAS B 4

MAS н 2

CAS B 1

X A $\mathbf{4}$ н 3

A S C $-\mathbf{T} 3$
A S - T 4

A S C - T
A S C $-T$
T

A S - T 8

C n A S B

TOYA I

NEURO

$C M I O D$

consens us

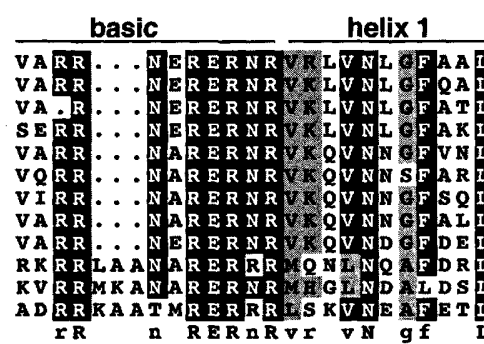

${ }_{1000}$

helix 2

Figure 1. (A) Amino acid sequence of CASH4 and comparison with other vertebrate members of the ASC family. CASH4 shows the highest homology with the chick ASH1 protein (Jasoni et al. 1994), the ortholog of the mouse MASH1 (Guillemot and Joyner 1993). The bHLH domain is well conserved between all the vertebrate ASC proteins, with a shorter loop than that of the fly ASC proteins. Two other regions (A and B) are also conserved between the vertebrate ASC proteins, in particular between CASH4 and the vertebrate ASHl proteins. (B) Alignment of the bHLH domain from the various ASC family members and members of other classes of bHLH proteins. The CASH4 bHLH domain shares the unique characteristics of the ASC bHLH domain, in particular a distinctive 13 amino acid) shorter basic region, as compared with other classes of bHLH proteins (Villares and Cabrera 1987; ASC, Alonso and Cabrera 1988; chick MyoD, Lin et al. 1989; Atonal, Jarman et al. 1993; CnASH, Grens et al. 1995; mouse NeuroD, Lee et al. 1995).

goxygenin (DIG)-labeled riboprobes. cash 4 transcripts are first detected at $\mathrm{HH} 5$ [stages according to Hamburger and Hamilton (1951)], at two major sites of expression: prospective blood islands in the extra-embryonic tissue of the area opaca, and the epiblast cells adjacent to Hensen's node and the anterior primitive streak that will give rise to the posterior CNS (Fig. 2A). cash4 expression in the blood islands resembles that of $s c 1 /$ tall and gata2, two genes that are expressed very early in the blood stem cells and that are essential to their normal development (Tsai et al. 1994; Shivdasani et al. 1995). cash4 expression precedes that of gata2 (data not shown), suggesting a very early role for cash 4 in the development of the primitive blood stem cells. Thus, like the fly ASC genes, which play roles in a range of developmental processes from sex determination to the formation of muscle, gut, and nervous system (for review, see Jan and Jan 1993), cash4 may also be involved in the generation of a number of different cell types. In this paper, however, we focus only on the expression of cash 4 in the developing nervous system and its potential proneural function in this tissue.

\section{cash4 expression in the developing CNS}

In the developing chick CNS, cash4 is expressed initially in epiblast cells on each side of the organizer region (i.e., next to Hensen's node and the anterior primitive streak) at HH5 (Fig. 2A,B). The boundaries of the cash4 domain are not sharp and there is also heterogeneity in the levels of cash4 expression within its domain; some cells express higher levels of cash4 mRNA than their immediate neighbors (Fig. 2C,D). Fate maps of the epiblast adjacent and posterior to the node at $\mathrm{HH} 5$ show that cells in the cash4 domain contribute extensively to the posterior CNS, comprising the posterior hindbrain and spinal cord (Spratt 1952; Schoenwolf and Alvarez 1989, 1991). We have confirmed this by using the lineage tracer $1,1^{\prime}$ dioctadecyl-3,3,3',3' tetramethyl indocarbocyanineperchlorate (DiI) to label groups of $\sim 25-30$ epiblast cells in the cash4-expressing domain at $\mathrm{HH} 5$, adjacent to the node and anterior primitive streak. After $12 \mathrm{hr}$ (HH10), DiI-labeled cells are found unilaterally within the developing posterior CNS, commencing in the posterior hindbrain at the level of somites 2-3 and extending within 


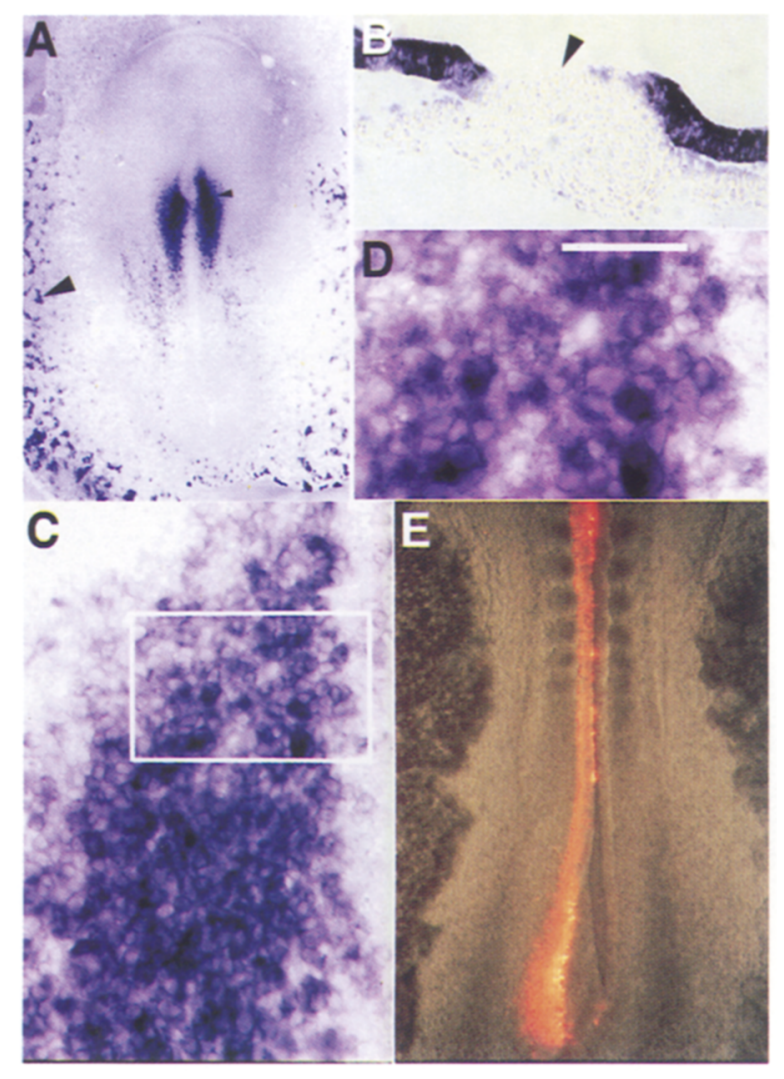

Figure 2. Initial pattern of $\operatorname{cash} 4$ expression and the fate of the first cash4-expressing cells. (A) cash4 mRNA is first detected in the epiblast adjacent and posterior to Hensen's node (small arrowhead) and in the developing blood islands (arrowhead) in extraembryonic tissue at $\mathrm{HH} 5$ (shown here slightly later at HH6-). (B) Transverse section through a stage HH5 Hensen's node. cash 4 expression is confined to the epiblast layer lateral to the node. Although a few cells expressing low levels of cash 4 may be present at the lateral edges of the node and anterior primitive streak, cash 4 transcripts are absent from the presumptive floor plate (arrowhead). (C) High magnification of $A$ depicting anterior region of the cash 4 domain (primitive streak is to the right). (D) High-power view of box in C. Single epiblast cells express cash 4 at higher levels than their immediate neighbors. Bar, $20 \mu \mathrm{m}$. (E) DiI-labeling of groups of 25-30 epiblast cells adjacent to Hensen's node/anterior primitive streak at HH5-6 reveals that cells in the initial cash 4 domain proliferate and rearrange so that they are distributed along the length of the posterior CNS including the open neural plate at $\mathrm{HH} 10$.

the spinal cord. In most cases $(15 / 20)$, labeled cells are present along the entire length of the spinal cord and in the open neural plate at the posterior-most end of the CNS (Fig. 2E), confirming that cells in the initial cash4 domain include precursors whose descendants become distributed throughout the posterior CNS.

At HH5-6, the primitive streak begins to regress to the caudal end of the embryo and the domain of cash4 expression retains its spatial relationship to the node (Fig. 3). This displacement of the cash 4 domain reflects the rostrocaudal sequence in which the posterior CNS is laid down (Schoenwolf and Alvarez 1989; Schoenwolf 1992).
As neurulation proceeds and the neural plate becomes morphologically distinct adjacent to Hensen's node, cash 4 transcripts are always present in the open neural plate but decrease as the neural folds elevate (Fig. 3A-D). When the posterior neuropore closes and primary neurulation is completed ( $\mathrm{HH} 11-12)$, the expression of cash 4 ceases in the developing CNS. Thus, cash 4 is specifically expressed during the expansion of the posterior nervous system, preceding the first signs of neuronal differentiation.

\section{cash4 is induced by Hensen's node}

The expression of cash 4 in presumptive posterior neural tissue close to Hensen's node at HH5 suggests that it may be induced by signals from the node, which is the source of neural-inducing signals in the chick embryo (Waddington 1932; Gallera 1971; Dias and Schoenwolf 1990; Storey et al. 1992). To test this possibility, we grafted nodes derived from HH5-6 quail embryos into the presumptive anterior neural plate of $\mathrm{HH} 3-3+$ chick embryos, a region that does not normally generate cells that express cash4. As a control, we carried out similar experiments in which we grafted quail-derived pieces of the posterior primitive streak, a region not normally flanked by cash4-expressing cells (Fig. 4A). All host embryos were maintained in New culture (New 1955) until they had developed to HH8-10, when they were analyzed using a chick-specific cash 4 riboprobe. The species specificity of the probe was confirmed by combining in situ hybridization with immunocytochemistry, using the QCPN antibody to identify grafted quail cells (Fig. $4 D$ ). In all cases (15/15), the grafted node induces cash4 expression in host tissue, whereas control grafts of posterior primitive streak do not (5/5) (Table 1; Fig. 4B-E). This result indicates that cash 4 expression can be induced by signals that emanate from Hensen's node at HH5-6.

As cash 4 expression moves in concert with the regressing node, it is possible that the node continues to provide cash4-inducing signals throughout regression. We tested this possibility by repeating the above quail/ chick grafting experiments with nodes from progressively older embryos $(\mathrm{HH} 7+-11)$. Nodes explanted from even the oldest stage (HH11) induce a dome-shaped region of raised host epithelium that has a diffuse, speckled pattern of cash4-expressing cells (Fig. 4F). Although the oldest nodes are the weakest inducers of cash4, they clearly retain the ability to elicit expression of this gene in the host epiblast (Table 1), demonstrating that cash4inducing signals are continually present in the node during its regression and for as long as cash 4 is normally expressed in the presumptive neural plate (up to $\mathrm{HH} 11$ ).

Signals from the regressing node induce cash4 expression in the extraembryonic epiblast

Our DiI-labeling study suggests that some descendants of the initial cash4-expressing cells retain expression of this gene as they shift posteriorly. Thus, signals provided by older nodes may serve largely to maintain cash 4 ex- 

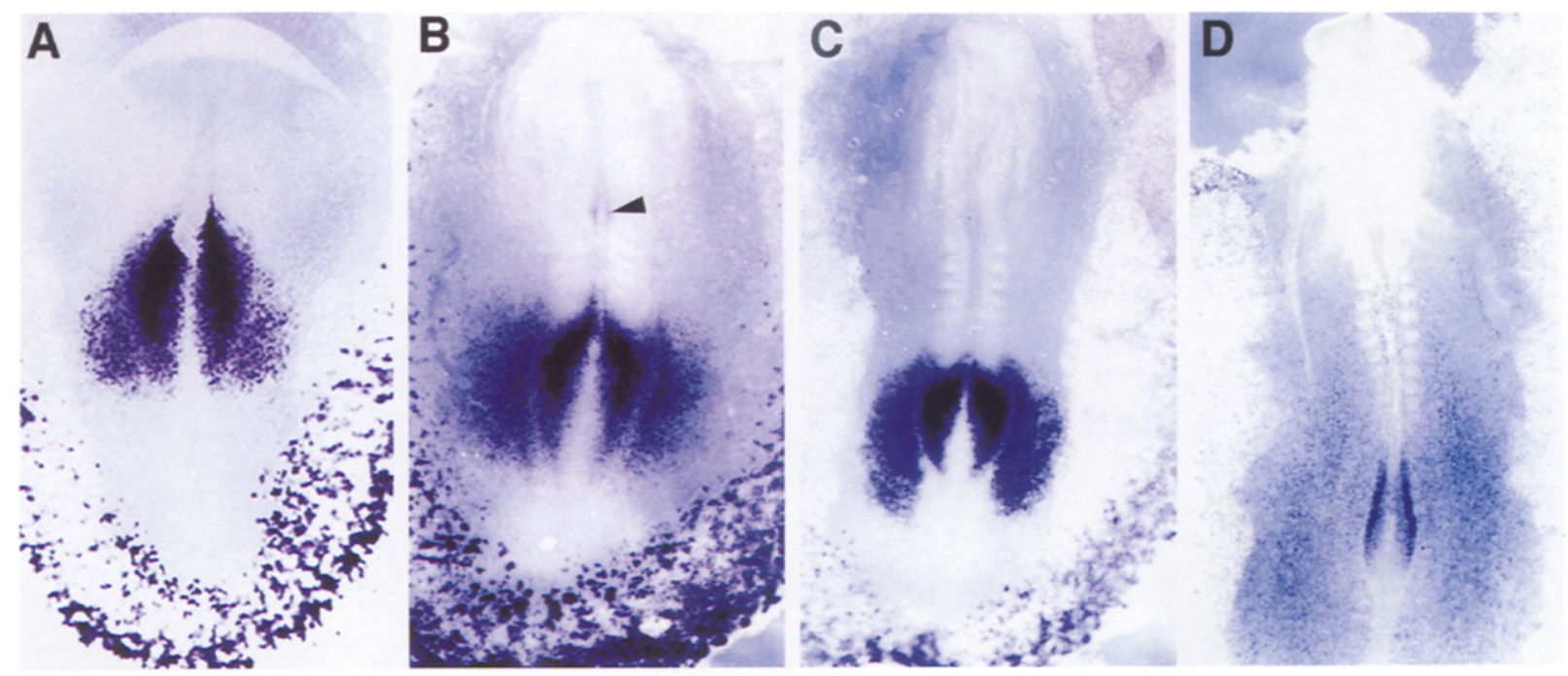

Figure 3. The dynamic pattern of cash 4 expression during development of the posterior CNS. (A) HH6 embryo. The cash4 domain of expression accompanies the regressing node/anterior primitive streak. (B) HH8 embryo. cash4 is now expressed in broadening domains on either side of the streak that include the nascent neural plate and more laterally prospective epidermis (after Spratt 1952). At HH8-9, cash4 is also expressed transiently in the neural plate just anterior to the first forming somite. This patch of expression is just beginning to appear in this embryo (arrowhead). (C) cash4 expression domain continues to shift posteriorly with the regressing node/primitive streak at HH9. (D) Reduced levels of cash4 are detected in the elevating neural plate at HH11.

pression in those cells, rather than to induce de novo expression of this gene. To assess whether the regressing node retains the ability to induce cash4 de novo, we therefore transplanted older nodes into the extraembryonic epiblast, a region that normally gives rise to extraembryonic membranes and that is unlikely to have been exposed to the early neural-inducing signals from Hensen's node (Waddington 1932; Gallera 1971; Storey et al. 1992, 1995). Nodes were explanted from quail embryos of HH5-10 and placed against the extraembryonic epiblast of chick HH3-3+ embryos, which were then allowed to develop to HH8-10 (Fig. 5A). In the majority of cases, HH5-6 nodes are able to induce cash4 expression in host epithelial cells overlying the graft (Table 1; Fig. 6B). Hensen's nodes derived from older embryos were also found to elicit cash4 expression in the extraembryonic epiblast (Table 1; Fig. 5C).

As cash4 is expressed in non-neural tissue in extraembryonic regions (see above), we confirmed that the cash4expressing cells induced by older nodes are indeed neural by also assaying for the ectopic expression of the neural specific marker Sax1 (an NK-1 class of homeodomain transcription factor expressed in the spinal cord; Spann et al. 1994). In most cases (12/19) nodes of HH7+-11 induce ectopic Sax1 expression, which like cash4 is found in a strip of thickened epithelial cells overlying the graft. By combining Sax1 in situ hybridization with immunocytochemistry for the quail specific antibody QCPN, we confirmed that Sax1 is induced in chick epithelial cells ( $9 / 9$ cases; Fig. 5D and E).

Together, these findings demonstrate that signals from the regressing node can induce de novo expression of both cash4 and the neural specific gene Sax1 in epiblast cells that do not normally give rise to neural tissue.
Thus, the organizer appears to remain a source of neural inducing signals during regression.

\section{FGF can induce cash4}

The confinement of cash 4 expression to the presumptive posterior regions of the CNS suggests that cash4 might be induced by a posteriorizing factor. We therefore tested whether FGF signaling, which has been demonstrated to have a posteriorizing effect during neural induction (for review, see Doniach 1995), may contribute to induction of cash 4 by the regressing Hensen's node. Heparincoated acrylic beads soaked in FGF4 or control beads (washed in PBS) were implanted beneath and in contact with the presumptive anterior neural plate of $\mathrm{HH} 3+\mathrm{em}-$ bryos (Fig. 6A,B). These embryos were cultured until HH9-10 and cash4 expression was monitored by wholemount in situ hybridization. Embryos implanted with FGF4 beads are characterized by the proliferation of tissue around the bead and the loss of anterior structures, such as optic lobes (a more detailed analysis of this phenotype will be presented elsewhere). In these embryos, cash4 expression is strongly induced in the cells closest to the implanted FGF4 bead (Table 2; Fig. 6C,D), and no ectopic cash 4 is induced in response to control PBSsoaked beads (Fig. 6E). These results suggest that a member of the FGF family of signaling molecules is involved in the activation of cash 4 expression in the presumptive posterior CNS.

\section{cash4 has proneural activity in fly and amphibian embryos}

The sequence conservation between cash4 and the fly ASC proteins, in particular in their bHLH domains, and 


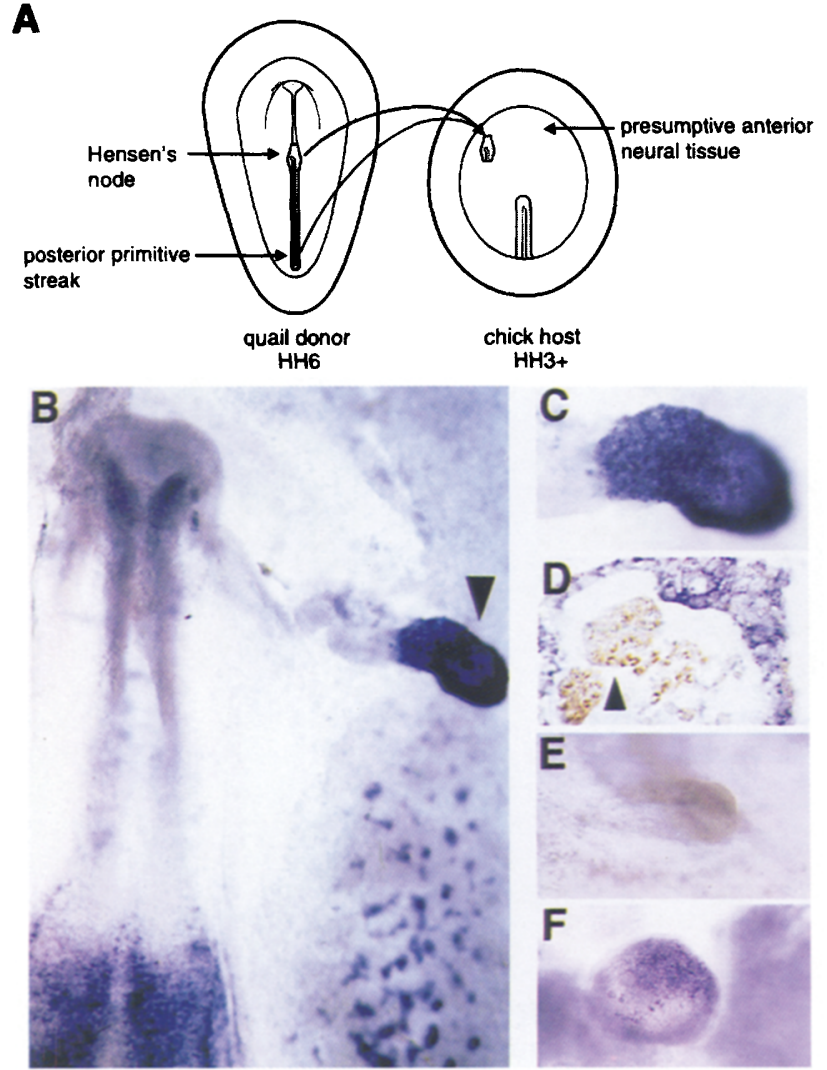

Figure 4. Hensen's node induces ectopic cash4 expression in the presumptive anterior neural plate. $(A)$ Schematic of grafting experiments: Quail nodes or pieces of posterior primitive streak derived from HH5-6 embryos were juxtaposed with the presumptive anterior neural plate of young chick host embryos. (B) Hensen's node (HH5-6) induces ectopic cash 4 expression following transplantation into the presumptive anterior neural plate (arrowhead). Node tissue is present beneath this region of ectopic cash 4 and extends from the host embryo, seen here in whole mount. $(C)$ Higher magnification of whole mount seen in $B$ showing ectopic cash4. $(D)$ Simultaneous detection of cash 4 mRNA and a quail-specific perinuclear antigen /recognized by Mab QCPN detected with a peroxidase conjugated secondary antibody reacted with diamino benzidine to give a brown precipitate) confirmed the species-specificity of the $3^{\prime}$ cash 4 probe. In this transverse section quail tissues (arrowhead) derived from a HH7+ Hensen's node (in this case placed in contact with the extraembryonic epiblast; see below) can be distinguished from chick host epiblast expressing cash4. $(E)$ Posterior primitive streak does not induce ectopic cash4 in presumptive anterior neural tissue (whole mount). (F) HHll Hensen's node induces scattered ectopic cash4 expression following grafting into presumptive anterior neural tissue (whole mount).

the striking pattern of cash4 expression in the developing nervous system may reflect a conserved function of these proteins as proneural factors during embryonic development. We investigated this possibility by testing whether CASH4 is able to promote neural development in Drosophila. We used the GAL4/UAS (upstream activating sequence) system (Brand and Perrimon 1993) to drive cash 4 expression during larval development. Flies expressing cash 4 in the scutellar primordium develop numerous ectopic bristles (Fig. 7A,B). This phenotype is indistinguishable from that obtained by equivalent expression of the Drosophila l'sc or sc genes (cf. Fig. 7B and Hinz et al. 1994, Fig. 2) showing that CASH4 can mimic the proneural activity of related fly ASC proteins.

To test whether CASH4 promotes bristle development directly or by activating the expression of endogenous proneural genes, we asked whether the proneural activity of $\mathrm{CASH} 4$ depends on $a c$ or $s c$, the endogenous proneural genes that normally drive the formation of sensory organs in the fly scutellum (Cubas et al. 1991; Skeath and Carroll 1991). Flies carrying $D f(1) s c^{10-1}$, a deletion that inactivates both $a c$ and $s c$, normally lack all sensory bristles (Fig. 7C; Villares and Cabrera 1987). However, expression of cash 4 in this genetic background is still able to induce ectopic scutellar bristles (Fig. 7D), indicating that the proneural activity of CASH4 in flies does not depend on the genes that normally specify adult bristles.

We also tested whether cash 4 can promote neurogenesis in vertebrate embryos by expressing this gene during early amphibian development. We injected cash4 mRNA into one blastomere of two-cell Xenopus embryos and assayed effects on neural development using a pan-neural marker, NCAM (Kintner and Melton 1987), and $N$ tubulin, which labels early differentiating neurons (Chitnis et al. 1995). Ectopic expression of cash4 leads to enlargement of the neural plate and an increase in neural precursor cells as measured by the expansion of the domain of NCAM expression (28/35 embryos; Fig. 7E). The number of subsequently differentiating cells expressing $N$-tubulin also is increased sharply, and extends outside the normal domains of neurogenesis (58/65 embryos; Fig. 7F). Thus, ectopic cash4 expression is able to promote the formation of neural precursors and, ultimately, the production of differentiated neurons.

\section{Discussion}

We have isolated a novel chick ASC homolog, cash4, and investigated its function during neural development. cash4 is the earliest known ASC homolog to be expressed in the chick nervous system, being first present in epiblast cells on either side of Hensen's node/anterior primitive streak at $\mathrm{HH} 5$. We show that these cells will

Table 1. Induction of chick cash $4 \mathrm{mRNA}$ by quail Hensen's node

\begin{tabular}{lcc}
\hline $\begin{array}{l}\text { Stage of } \\
\text { Hensen's node }\end{array}$ & Graft position & $\begin{array}{c}\text { Frequency of } \\
\text { cash4 induction }\end{array}$ \\
\hline HH5-6 & $\begin{array}{c}\text { presumptive anterior } \\
\text { neural plate } \\
\text { presumptive anterior } \\
\text { neural plate }\end{array}$ & $15 / 15$ \\
HH7+-11 & $\begin{array}{c}\text { extraembryonic epiblast } \\
\text { extraembryonic epiblast }\end{array}$ & $9 / 9$ \\
HH5-6 & extraembryonic epiblast & $9 / 10$ \\
HH6+-8+ & & $5 / 10$ \\
HH9-10 & &
\end{tabular}




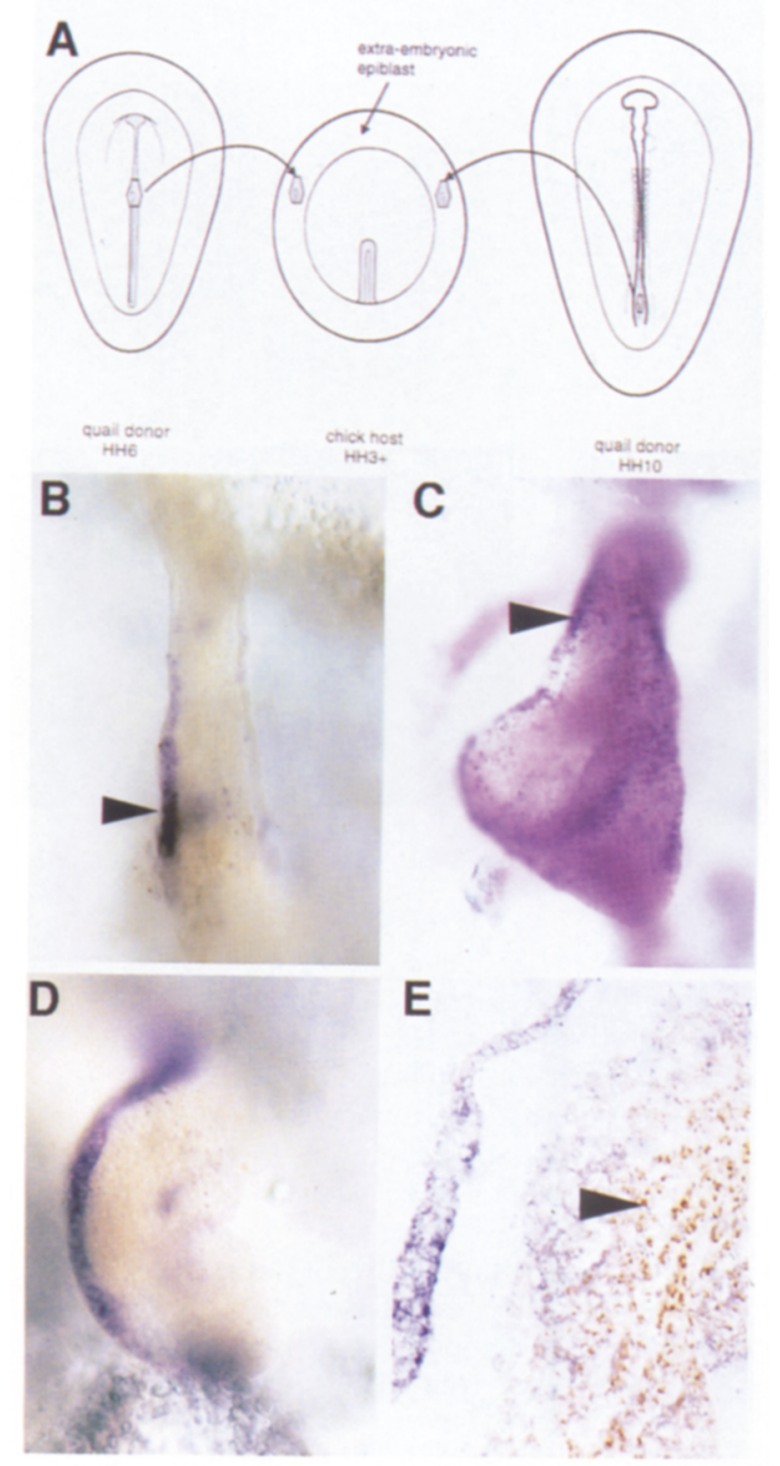

Figure 5. Hensen's node induces cash 4 and Sax1 expression in extraembryonic epiblast cells. (A) Schematic showing the position of Hensen's nodes derived from progressively older stages transplanted in contact with extraembryonic epiblast. $(B)$ Hensen's nodes of HH6 induce ectopic cash4 (arrowhead) when placed in contact with the extraembryonic epiblast (whole mount). $(C)$ Nodes derived from later stages (HH9-10) also retain the ability to induce ectopic cash 4 (arrowhead) in extraembryonic epiblast (whole mount). (D) Old nodes (in this case $\mathrm{HH} 8$ induce ectopic expression of the neural specific marker Sax1 (whole mount). (E) The induction of Sax1 in the chick host cells was confirmed by simultaneous detection of this gene and a quail-specific antigen (arrowhead; detected as described in Fig. 5) shown here in a transverse section of one of these ectopic structures. No Sax1-expressing cells were found to contain the quail antigen. cash 4 and $S a x 1$ are induced in only a thickened epithelium and in most cases are present on the side of ectopic structures facing the host axis; this may reflect changes in competence to respond to neural-inducing signals observed across the lateral extent of the extraembryonic epiblast (Storey et al. 1992).

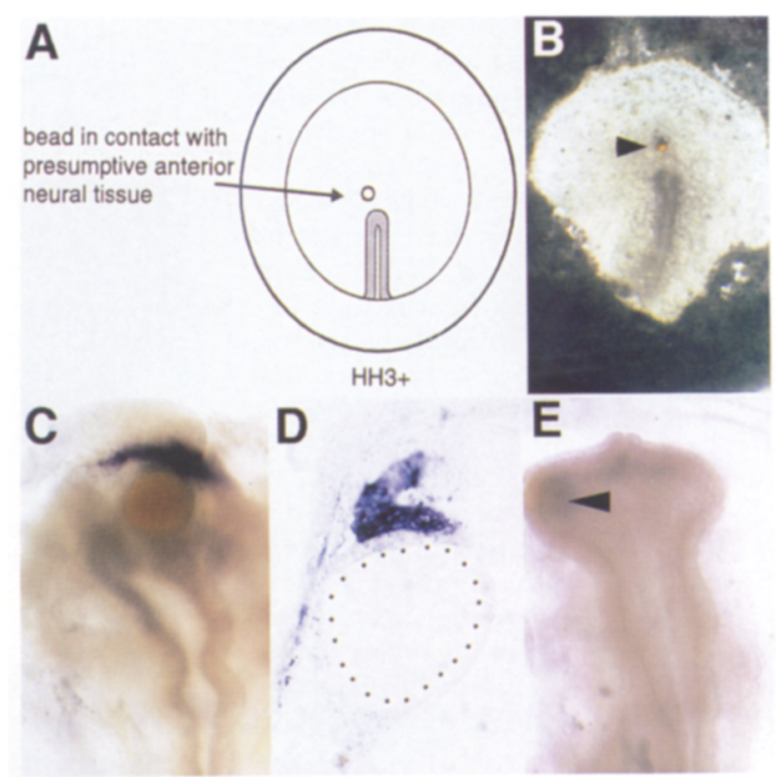

Figure 6. Induction of cash4 by local expression of FGF4 in presumptive anterior neural tissue. $(A)$ Schematic of FGF bead grafting experiments. (B) FGF4-soaked bead (arrowhead) grafted in contact with the presumptive anterior neural tissue. $(C)$ Ectopic cash 4 expression is induced in the anterior CNS by FGF4 beads. This phenotype is also characterized by the loss of characteristic anterior neural morphology such as the optic lobes. (D) Transverse section through C. cash 4 expression is localized in cells in the immediate vicinity of the bead (dotted outline). (E) Control PBS beads (arrowhead) do not induce cash4 or affect morphogenesis of the anterior CNS.

contribute to the posterior CNS and that expression of cash4 is induced by signals emanating from Hensen's node, throughout its regression. We demonstrate that the product of cash 4 has proneural activity: It can function as an ASC gene product in the fly and can promote neural plate formation in vertebrate embryos. Together these results suggest a proneural function for cash4 in the chick, providing a link between node-derived signals (including FGF) and the molecular machinery responsible for the implementation of the neural program in posterior regions of the chick embryo.

cash4 expression defines neural precursors of the chick posterior CNS

In the developing chick CNS, cash4 expression is initiated at HH5, in the epiblast adjacent to Hensen's node and anterior primitive streak. Previous studies (Spratt

Table 2. Induction of cash $4 \mathrm{mRNA}$ by local overexpression of FGF4 in the presumptive anterior neural plate

\begin{tabular}{lcc}
\hline Implant & Loss of optic lobe(s) & Ectopic cash4 \\
\hline FGF4 beads & $18 / 28$ & $11 / 12$ \\
PBS beads & $0 / 28$ & $0 / 12$ \\
\hline
\end{tabular}


Figure 7. Proneural effects of cash4 expression in Drosophila and Xenopus embryos. (A) Wild-type pattern of scutellar sensory organs consists of four bristles (arrowheads). (B) cash4 expression in the prospective scutellum, driven by the Gal4455.2 line, results in ectopic development of bristles. (C) Absence of bristles on the adult thorax including the scutellum in a $D f(1) s c^{10-1} \mathrm{fly}$, in which ac and sc function are eliminated. (D) cash4 expression in a $s c^{10-1}$ background $\left(s c^{10-1}\right.$; Gal4455.2; UAScash4) still results in the development of ectopic scutellar bristles. (E) Unilateral expression of cash4 in Xenopus embryos, following injection of cash $4 \mathrm{mRNA}$ in one cell of the two-cell stage embryo, leads to hypertrophy of the neural plate on the injected side, revealed by the expansion of the NCAM expression domain. $(F)$ Ectopic primary neurons induced by cash 4 , as revealed by $N$-tubulin positive cells outside the normal domains of primary neurogenesis. In $E$ and $F$, injected side of embryos is uppermost, and white arrows show midlines of the embryos.
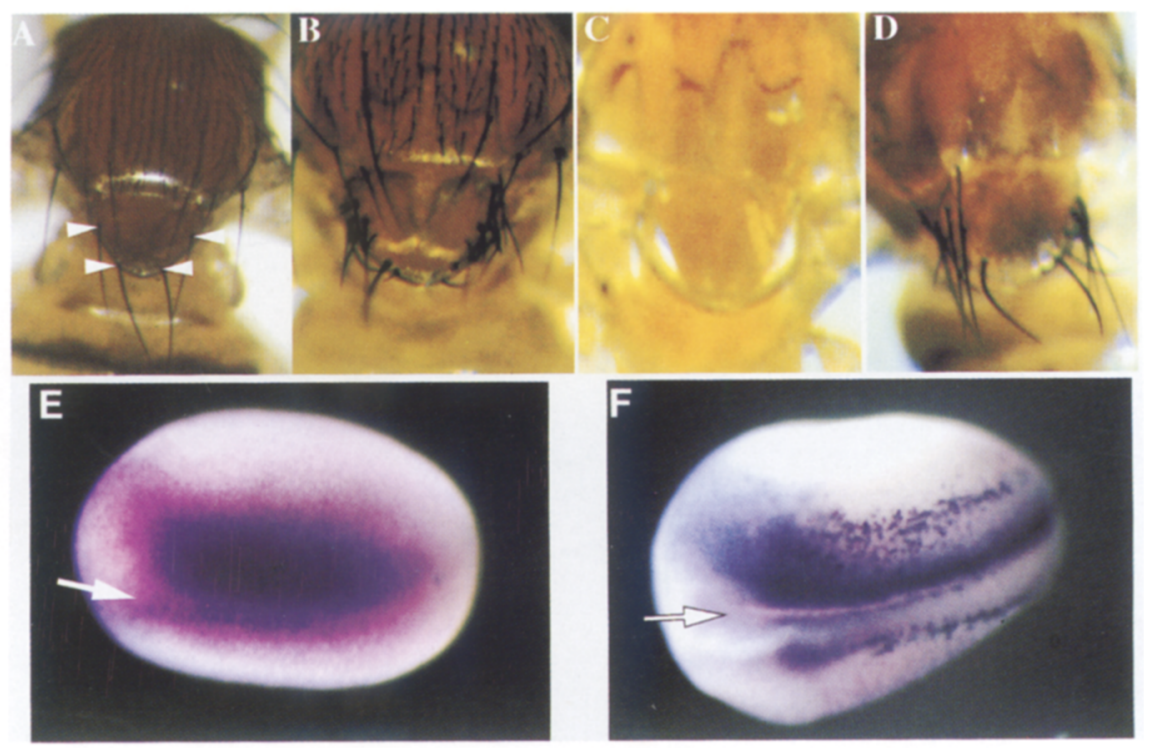

1952; Schoenwolf and Alvarez 1989; Schoenwolf and Sheard 1990; Schoenwolf and Alvarez 1991) indicate that this region of epiblast constitutes a primordium of the posterior nervous system, and it has been proposed that the posterior CNS is generated by the elongation of such primordia, through movement and proliferation of neural precursors present within this cell population (see Schoenwolf and Alvarez 1989; Storey et al. 1992). Our DiI-labeling study confirms that indeed cells in the initial cash4 domain are neural precursors fated to contribute to extensive anteroposterior regions of the CNS, from the posterior hindbrain and along the length of the spinal cord.

Whereas lineage tracing of groups of cells within the initial cash4 domain results in labeling confined almost exclusively to the neural tube, it is not clear whether all cells in the posterior CNS derive from the initial cash4expressing domain, or whether there is an admixture of cells recruited later from elsewhere (see below). In any case, essentially all cells at each level of the prospective posterior hindbrain and spinal cord express cash4 for a limited period, resulting in a rostrocaudal wave of cash4 expression that foreshadows neurogenesis in the developing posterior CNS. Given the proneural activity of the cash4 gene product in Drosophila and Xenopus, these observations strongly suggest that cash4 plays a part in conferring neural potential on the precursor cells that will give rise to the posterior CNS. Indeed, the cells of the prospective floor plate do not express cash4 (see Fig. $2 \mathrm{~B})$ and do not subsequently give rise to neurons.

The heterogeneous pattern of cash 4 expression within the newly formed neural plate may reflect the different developmental states of cells in this region. We favor a model in which the cells expressing higher levels of cash 4 may become specified as the founder neural precursors of the posterior CNS, much as high levels of ASC expression direct Drosophila neuroectodermal cells to become neuroblasts, the founder stem cells of the fly nervous system (for review, see Skeath and Carroll 1994). Alternatively, higher levels of cash4 expression could promote neuronal differentiation and drive those cells directly toward terminal differentiation. However, this hypothesis is unlikely because cash 4 expression does not correlate with the temporal sequence of neuronal production in the developing posterior CNS, as marked by the expression of C-Delta-1 in newly born neurons (Sechrist and Bronner-Fraser 1991; Henrique et al. 1995). Further, cells with high cash4 levels incorporate bromodeoxyuridine (data not shown) and therefore are not differentiating postmitotic neurons. Single-cell labeling to define early neural lineages arising adjacent to the node and anterior primitive streak will allow us to confirm our hypothesis.

As suggested previously (Lee et al. 1995; Chitnis and Kintner 1996; Ma et al. 1996), neurogenesis in vertebrate embryos may be controlled by a cascade of ASC homologs or functionally related genes whose sequential expression in neural cells regulates different steps in the progression toward their final fates. If so, the early and transient expression of cash 4 in neural precursors places it upstream of all related bHLH-encoding genes currently identified in higher vertebrates, including mash1, neurogenin, and neuroD. These are expressed later in descendent cells (mash1, neurogenin in neuronal progenitors; neuroD in differentiating neurons), and must regulate subsequent steps in neurogenesis. 
cash4 is induced continuously by the regressing node/anterior primitive streak

cash4 expression is induced ectopically when Hensen's node from stage HH5-6 is grafted into the anterior neural plate, whereas grafts of posterior primitive streak do not have this effect. The late-phase node, therefore, is a source of cash4-inducing signals. Further, the rostrocaudal displacement of the cash4 expression domain in concert with the regressing node suggests that cash4-inducing activity is present at all stages of node regression, while the posterior CNS is being laid down. This is confirmed by our finding that old nodes (up to stage $\mathrm{HH} 10$ ) retain the ability to induce cash 4 even in extraembryonic epiblast cells, which normally give rise only to extraembryonic membranes. In these experiments, induction of cash4 expression correlates with induction of neural characteristics, as revealed by the ectopic expression of neural-specific marker $S a x 1$ in response to the explanted node. Our results thus show that neural-inducing signals are present in the node during regression, and persist for longer than reported in previous studies (Dias and Schoenwolf 1990; Storey et al. 1992; but see Kintner and Dodd 1991). These findings, together with our lineage data, indicate that during normal development, cash 4 expression could be maintained in cells that move posteriorly alongside the regressing node as well as being initiated in successive cell populations. Indeed, Selleck and Bronner-Fraser (1995) have shown that as late as $\mathrm{HHIO}$ the open neural plate contains pluripotent cells that can give rise to both epidermal and neural cell types, implying that continuing inductive signals are required to confer an appropriately neural character on all the cells of the posterior neural plate.

\section{cash4 is induced by FGF}

The restricted expression of cash 4 in the presumptive posterior CNS, and its onset when the node ceases to induce anterior neural tissue but retains the ability to induce genes characteristic of the posterior neural tissue (Storey et al., 1992; present results), suggest that cash4 is activated by signals associated with the formation of the posterior CNS. FGFs are expressed in the regressing node and primitive streak of the chick embryo (Mahmood et al. 1995; Riese et al. 1995; K.G. Storey and J.K. Heath, unpubl.) and it is known that FGF signaling has both general posteriorizing effects (Slack and Tannahill 1992) as well as specific caudalizing activity in the amphibian CNS /Okamoto and Kengaku 1993; Cox and HemmatiBrivanlou 1995; Kengaku and Okamoto 1995; Lamb and Harland 1995; Launay et al. 1996). Here we have shown that FGF4 induces ectopic expression of cash4 when overexpressed in the presumptive anterior CNS of the chick and that it can therefore mimic the cash4-inducing signals of Hensen's node. The expression of cash4 in cells in the immediate vicinity of FGF beads suggests that the induction of this transcription factor is a consequence of direct exposure to FGF. These findings support a role for FGF in the generation of the posterior CNS in the chick embryo and are consistent with a function in both neural induction and anteroposterior patterning of the CNS, as has been reported recently in amphibian embryos (Okamoto and Kengaku 1993; Cox and Hemmati-Brivanlou 1995; Kengaku and Okamoto 1995; Lamb and Harland 1995; Launay et al. 1996).

\section{cash4 has proneural activity in both vertebrate and Drosophila embryos}

The ability of cash4 to rescue sensory organ formation in Drosophila mutants lacking endogenous $a c$ and $s c$ genes represents the first example in which a vertebrate ASC homolog has been shown to substitute for a Drosophila proneural gene. Like l'sc (Hinz et al. 1994), cash4 induces the formation of ectopic bristles in flies, independent of endogenous $a c$ and $s c$ genes. Thus, CASH4 appears to retain the transcriptional specificity that mediates the proneural function of fly ASC proteins. These results are consistent with the finding that the bHLH domain is a major determinant of the functional activity of the ASC family of proteins during neural development (Hinz et al. 1994). However, we cannot exclude the possibility that cash4 recruits other endogenous proneural activities that do not normally function during imaginal bristle development.

Conservation of the proneural activity of cash4 is demonstrated further by its ability to direct cells toward a neural fate during vertebrate development: When ectopically expressed in Xenopus embryos, cash4 leads to an expansion of the neural plate and overproduction of primary neurons. This result differs from findings with xash3, another ASC homolog, and ngnr-1 and neuroD, two bHLH-encoding genes related to the Drosophila proneural gene atonal. Although overexpression of xash 3 in Xenopus embryos also promotes the formation of neural precursors, leading to a similar expansion of the neural plate, the actual number of differentiated neurons in the neural tube is diminished (Ferreiro et al. 1994; Turner and Weintraub 1994), probably because xash3 strongly activates the genes involved in lateral inhibition (Chitnis and Kintner 1996). In contrast, overexpression of ngnr-1 and neuroD results in an overproduction of neurons, but without any enlargement of the neural tissue, suggesting that these genes function during neuronal differentiation, ngnr-1 being upstream of neuroD (Lee et al. 1995; Ma et al. 1996). cash4 in this assay, therefore, appears to behave both as determination and differentiation factor, as it mimics the action of xash3, neuroD, and ngnr-1.

Structural differences between CASH4 and XASH3, which are found mainly outside the bHLH domain, could account for the extra activity of CASH4. Alternatively, the avian protein CASH4 may not be recognized by the Xenopus inhibitors that act on the endogenous proneural proteins and for that reason may be able to promote neuronal differentiation in frog embryos. A similar situation occurs when the myogenic function of MyoD is tested by ectopic expression in early Xenopus embryos: Whereas mouse MyoD is translocated into the 
nucleus and activates the myogenic program, Xenopus MyoD is sequestered in the cytoplasm by specific endogenous inhibitors and is thus unable to initiate transcription of the muscle-specific genes (Rupp et al. 1994). This second alternative is consistent with the proposed existence of a cascade of bHLH proteins acting during vertebrate neurogenesis and possessing different susceptibilities to specific inhibitors (Lee et al. 1995). The isolation of the Xenopus counterpart of cash 4 would allow us to distinguish between the two explanations, and help to elucidate the role of different bHLH proteins during vertebrate neural development. Nevertheless, from our experiments we can conclude that cash 4 is able to function as a proneural gene in that it is able to promote the formation of neural precursors in a vertebrate embryo.

\section{Making the posterior CNS}

The existence of independent molecular mechanisms for the generation of head and trunk regions of the vertebrate embryo is demonstrated dramatically by the phenotype of mouse embryos with a targeted mutation in the homeobox transcription factor Lim-1 (Shawlot and Behringer 1995). In these embryos, the head fails to form and the body axis begins in the hindbrain, apparently a result of a deficit in the activity of the node in the early phase of neural induction. However, an organized node is present later and posterior regions of CNS form correctly. Genesis of the posterior nervous system, therefore, does not depend on the presence of the rudiment of the anterior nervous system. These findings, together with our results, are consistent with the idea that the posterior CNS derives from an initial primordium (Schoenwolf and Alvarez 1989, 1991; Storey et al. 1992) that is induced by a specific combination of signals, including FGF, arising from the late-phase organizer. In addition, our results indicate that there could also be a progressive recruitment of new epiblast cells into the neural pathway in response to signals provided by the regressing node, indicating that neural induction may continue during node/primitive streak regression. The expression of cash4 in precursor cells of the posterior nervous system reflects exposure to this later combination of signals and is an early manifestation of the distinct molecular mechanisms that underlie the formation of the posterior CNS.

We have argued that cash 4 has the characteristics of a vertebrate proneural gene. It is expressed transiently in neural precursors, before neuronal differentiation begins and prior to other known bHLH proteins, and it displays proneural activity in both Drosophila and Xenopus. Further, its expression is induced by Hensen's node, the in vivo source of neural-inducing signals, and by FGF, a candidate posteriorizing signal present in this region. We therefore suggest that cash4 functions as a neural determination gene specifying the neural precursors that will generate the avian posterior nervous system, and that it may be the first of a cascade of bHLH factors (Lee et al. 1995; Chitnis and Kintner 1996) that would function se- quentially to implement the neural program in the wake of the regressing node.

\section{Materials and methods}

DNA cloning

The initial cDNA fragment from cash 4 was obtained by PCR using the following degenerate primers: $5^{\prime}-(\mathrm{C} / \mathrm{A}) \mathrm{GIAACG}(\mathrm{C} /$ $\mathrm{A} / \mathrm{I}(\mathrm{C} / \mathrm{A}) \mathrm{GIGAG}(\mathrm{C} / \mathrm{A}) \mathrm{GNAA}(\mathrm{C} / \mathrm{T}) \mid \mathrm{C} / \mathrm{A} / \mathrm{G}-3^{\prime}$ and $5^{\prime}-\mathrm{AG}-$ IGTCTC(G/C)AC(C/T)TT/T/G)CTCAT/C/T)TT-3' that correspond, respectively, to the sequences RN(E/A)RERNR and KMSKVETL, located on helices 1 and 2 of the AS-C/MASH family of proteins. A fragment of $112 \mathrm{bp}$ corresponding to a new ASC homolog was obtained by PCR $\left(94^{\circ} \mathrm{C}\right.$ for $30 \mathrm{sec}, 50^{\circ} \mathrm{C}$ for $2 \mathrm{~min}$, $72^{\circ} \mathrm{C}$ for $30 \mathrm{sec}, 40 \mathrm{cycles}$ ) using cDNA prepared from stage $4-10$ chicken embryos. This fragment was then used to screen a random-primed cDNA library in $\lambda g t 10$, prepared from stage 10-14 chick embryos, and one positive clone was isolated from $10^{6}$ original plaques. This clone contained an insert of $\sim 1.4 \mathrm{~kb}$ that was fully sequenced using the Sequenase kit (Amersham). The CASH4 sequence has been deposited in GenBank [accession no. U89138 (Bank It 95903)].

\section{In situ hybridization}

Chicken embryos were collected at the appropriate stages and fixed in $4 \%$ formaldehyde/PBS for $1 \mathrm{hr}$ to overnight. Wholemount in situ hybridization on these embryos was done according to Henrique et al. (1995). After the color reaction, some embryos were refixed in $4 \%$ formaldehyde/PBS with $0.1 \%$ glutaraldehyde, wax-embedded, and sectioned. A cash 4 3' end fragment was subcloned in pKS (Stratagene) to generate an RNA probe that is specific for chick embryos. This probe did not give a detectable signal in quail embryos. Sax1 cDNA was kindly provided by Dr. Yosef Gruenbaum (Spann et al. 1994).

\section{Fly experiments}

The entire cash 4 coding region (a 541-bp fragment from the BgII site just upstream of the initial ATG to the Mboll site just after the stop codon) was subcloned into $p U A S T$ (Brand and Perrimon 19931, and germ-line transformants were generated by P element-mediated transformation (Rubin and Spradling 1982). Several independent transformant lines were established that behaved similarly, one of which is documented in this paper. The activator line Gal4455.2 that is restricted to the presumptive scutellum (Hinz et al. 1994) was kindly provided by J. CamposOrtega (University of Köln, Germany), and the $D f(1) s c^{10-1}$ flies were obtained from F. Jiménez (Universidad Autonoma, Madrid, Spain). Crosses were maintained at $25^{\circ} \mathrm{C}$.

\section{Frog experiments}

The entire cash 4 coding region was subcloned in the vector pCS2+ (Turner and Weintraub 1994). After linearization with NotI, the vector was transcribed in vitro with SP6 polymerase in the presence of GpppG to produce capped cash4 RNA. One nanogram of cash4 RNA along with $0.2 \mathrm{ng}$ of synthetic lacZ RNA was injected in a volume of $10 \mathrm{nl}$ into one cell of a twocell-stage embryo. As a negative control, embryos were similarly injected with just lacZ RNA. At early neurulae stages, the injected embryos were fixed, reacted with X-Gal to reveal the distribution of the lacZ tracer, and then double-stained for either NCAM or N-tubulin transcripts, using whole-mount in 
situ hybridization (Chitnis et al. 1995). Double-stained embryos were postfixed and photographed in whole mount.

\section{DiI-labeling}

The use of DiI (Molecular Probes), as a dye for fate mapping studies has been described in detail elsewhere (e.g., Stern 1990). Groups of epiblast cells adjacent to node and anterior primitive streak were labeled at HH5-6. Following incubation, all DiIlabeled embryos were fixed in $4 \%$ buffered formol saline at $\mathrm{pH}$ 7.0 and viewed by epifluoresence (peak excitation $484 \mathrm{~nm}$ ).

\section{Grafting and culture techniques}

Quail-derived nodes or pieces of posterior primitive streak $(\sim 150 \times 150 \mu \mathrm{m})$ were excised and transplanted into chick host embryos of HH3-3+ prepared in New culture (New 1955) as described by Storey et al. (1992). Hensen's nodes from stages (5-11) were grafted either in contact with the presumptive anterior neural plate or with the extraembryonic epiblast of a host embryo and then maintained in a humid atmosphere at $38^{\circ} \mathrm{C}$ for up to $20 \mathrm{hr}$.

\section{Immunocytochemistry after in situ hybridization}

In situ hybridization techniques were combined with an antiquail antibody $/ \mathrm{QCPN}$; supernatant was obtained from the Developmental Studies Hybridoma Bank maintained by the Department of Pharmacology and Molecular Sciences, John Hopkins University School of Medicine, Baltimore, MD, and the Department of Biological Sciences, University of Iowa, Iowa City, under contract N01HD-6-2915), to ascertain the origin of cells expressing cash4 or Sax1. Following in situ hybridization embryos were washed in PBS and fixed overnight in formol saline at $4^{\circ} \mathrm{C}$, washed in PBS, and placed in a blocking solution [PBS containing 3\% BSA, 1\% Triton X-100, 0.01\% thimerosal, and $5 \%$ heat-inactivated normal goat serum (NGS)] for $4 \mathrm{hr}$ at room temperature. QCPN supernatant was added 1:10 and embryos incubated for 3 days at $4^{\circ} \mathrm{C}$. After extensive washing in PBS, embryos were incubated in blocking solution with peroxidase-conjugated goat anti-mouse IgG antibody (Jackson ImmunoResearch) (1:500) overnight at $4^{\circ} \mathrm{C}$. Embryos were then washed and underwent the usual diaminobenzidine tetrahydrochloride reaction, postfixed in $4 \%$ formol saline $/ 0.1 \%$ gluteraldehyde, and wax-sectioned following standard methods.

\section{Implanting FGF4 soaked beads}

Heparin-coated acrylic beads $(75-150 \mu \mathrm{m}$ in diameter; Sigma H5263) were soaked in $780 \mu \mathrm{g} / \mathrm{ml}$ of Human FGF4 for $30 \mathrm{~min}$ at room temperature and washed in PBS prior to implantation. Heparin-coated beads just washed with PBS were used as controls. Embryos at $\mathrm{HH} 3-3+$ were set up in New culture and a small slit made in the hypoblast cell layer lateral and slightly anterior to the tip of the primitive streak. One bead was implanted in each embryo by pushing it through the slit in the hypoblast so that the bead made direct contact with underlying epiblast cells of the presumptive anterior neural plate. Embryos with implanted beads were allowed to develop for 20-24 hr prior to in situ hybridization procedures to detect cash 4 mRNA.

\section{Acknowledgments}

We thank Dr. Helen Skaer and Prof. Claudio Stern for helpful comments on the manuscript, Dr. Yosi Gruenbaum for the gift of the Sax1 probe, Mr. Geoff Carlson for technical assistance, and Terry Richards and Colin Beesley for help with artwork. We are particularly grateful to Gerardo Jiménez for his invaluable assistance with the Drosophila experiments. This research is supported by Wellcome Trust grants to K.G.S. and J.K.H. and by the Imperial Cancer Research Fund. D.I.-H. is an International Research Scholar of the Howard Hughes Medical Institute.

The publication costs of this article were defrayed in part by payment of page charges. This article must therefore be hereby marked "advertisement" in accordance with 18 USC section 1734 solely to indicate this fact.

\section{References}

Akazawa, C., M. Ishibashi, C. Shimizu, S. Nakanishi and R. Kageyama. 1995. A mammalian helix-loop-helix factor structurally related to the product of Drosophila proneural gene atonal is a positive transcriptional regulator expressed in the developing nervous system. J. Biol. Chem. 270: 87308738.

Alonso, M.C. and C.V. Cabrera. 1988. The achaete-scute gene complex of Drosophila melanogaster comprises four homologous genes. EMBO I. 7: 2585-2591.

Beddington, R.S. 1994. Induction of a second neural axis by the mouse node. Development 120: 613-620.

Brand, A.H. and N. Perrimon. 1993. Targeted gene expression as a means of altering cell fates and generating dominant phenotypes. Development 118: 401-415.

Campos-Ortega, J. 1993. Early neurogenesis in Drosophila melanogaster. In The development of Drosophila melanogaster (ed. M. Bate and A. Martinez Arias), pp. 1091-1129. Cold Spring Harbor Laboratory Press, Cold Spring Harbor, NY.

Campuzano, S. and J. Modolell. 1992. Patterning of the Drosophila nervous system: The Achaete-Scute gene complex. Trends Genet. 8: 202-208.

Chitnis, A. and C. Kintner. 1996. Sensitivity of proneural genes to lateral inhibition affects the pattern of primary neurons in Xenopus embryos. Development 122: 2295-2301.

Chitnis, A., D. Henrique, J. Lewis, D. Ish-Horowicz, and C. Kintner. 1995. Primary neurogenesis in Xenopus embryos regulated by a homologue of the Drosophila neurogenic gene Delta. Nature 375: 761-766.

Cox, W.G. and A. Hemmati-Brivanlou. 1995. Caudalization of neural fate by tissue recombination and bFGF. Development 121: 4349-4358.

Crossley, P.H., S. Martinez, and G.R. Martin. 1996. Midbrain development induced by FGF8 in the chick embryo. Nature 380: 66-68.

Cubas, P., J.F. de Celis, S. Campuzano, and J. Modolell. 1991. Proneural clusters of achaete-scute expression and the generation of sensory organs in the Drosophila imaginal wing disk. Genes \& Dev. 5: 996-1008.

Dambly-Chaudière, C. and A. Ghysen. 1987. Independent subpatterns of sense organs require independent genes of the achaete-scute in Drosophila larvae. Genes \& Dev. 1:297306.

Dias, M.S. and G.C. Schoenwolf. 1990. Formation of ectopic neurepithelium in chick blastoderms: Age-related capacities for induction and self-differentiation following transplantation of quail Hensen's nodes. Anat. Rec. 228: 437-448.

Doniach, T. 1995. Basic FGF as an inducer of anteroposterior neural pattern. Cell 83: 1067-1070.

Ferreiro, B., P. Skoglund, A. Bailey, R. Dorsky, and W.A. Harris. 1992. XASH1, a Xenopus homolog of achaete-scute: A proneural gene in anterior regions of the vertebrate CNS. Mech. Dev. 40: 25-36. 
Ferreiro, B., C. Kintner, K. Zimmerman, D. Anderson, and W.A. Harris. 1994. XASH genes promote neurogenesis in Xenopus embryos. Development 120: 3649-3655.

Gallera, J. 1971. Primary induction in birds. Adv. Morphog. 9: $149-180$.

Ghysen, A. and C. Dambly-Chaudière. 1993. The specification of sensory neuron identity in Drosophila. BioEssays 15: 293-298.

Gordon, M.K., J.S. Mumm, R.A. Davis, D.J. Holcomb, and A.L. Calof. 1995. Dynamics of MASH1 expression in vitro and in vivo suggest a non-stem cell site of MASH1 action in the olfactory receptor neuron lineage. Mol. Cell. Neurobiol. 6: 363-379.

Grens, A., E. Mason, J.L. Marsh, and H.R. Bode. 1995. Evolutionary conservation of a cell fate specification gene: The Hydra achaete-scute homolog has proneural activity in Drosophila. Development 121: 4027-4035.

Guillemot, F. and A.L. Joyner. 1993. Dynamic expression of the murine Achaete-Scute homologue Mash-1 in the developing nervous system. Mech. Dev. 42: 171-185.

Guillemot, F., L.C. Lo, J.E. Johnson, A. Auerbach, D.J. Anderson, and A.L. Joyner. 1993. Mammalian achaete-scute homolog 1 is required for the early development of olfactory and autonomic neurons. Cell 75: 463-476.

Hamburger, V. 1988. The heritage of experimental embryology. In Hans Spemann and the Organiser (ed. V. Hamburger), pp. 46-92, Oxford University Press, New York, NY.

Hamburger, V. and H.L. Hamilton. 1951. A series of normal stages in the development of the chick. J. Morph. 88: 49-92.

Hemmati-Brivanlou, A., O.G. Kelly, and D.A. Melton. 1994. Follistatin, an antagonist of activin, is expressed in the Spemann organizer and displays direct neuralizing activity. Cell 77: 283-295.

Henrique, D., J. Adam, A. Myat, A. Chitnis, J. Lewis, and D. Ish-Horowicz. 1995. Expression of a Delta homologue in prospective neurons of the chick. Nature 375: 787-790.

Hinz, U., B. Giebel, and J.A. Campos-Ortega. 1994. The basichelix-loop-helix domain of Drosophila Lethal of Scute protein is sufficient for proneural function and activates neurogenic genes. Cell 76: 77-87.

Jan, Y.N. and L.Y. Jan. 1993. The peripheral nervous system. In The development of Drosophila melanogaster (ed. M. Bate and A. Martinez Arias), pp. 1207-1244, Cold Spring Harbor Laboratory Press, Cold Spring Harbor, NY.

- 1994. Neuronal cell fate specification in Drosophila. Curr. Opin. Neurobiol. 4: 8-13.

Jarman, A.P., Y. Grau, L.Y. Jan, and Y.N. Jan. 1993. atonal is a proneural gene that directs chordotonal organ formation in the Drosophila peripheral nervous system. Cell 73: 13071321.

Jasoni, C.L., M.B. Walker, M.D. Morris, and T.A. Reh. 1994. A chicken achaete-scute homolog (CASH-1) is expressed in a temporally and spatially discrete manner in the developing nervous system. Development 120: 769-783.

Jiménez, F. and J.A. Campos-Ortega. 1990. Defective neuroblast commitment in mutants of the achaete-scute complex and adjacent genes of Drosophila melanogaster. Neuron 5: 81-89.

Johnson, J.E., S.J. Birren, and D.J. Anderson. 1990. Rat homologs of Drosophila achaete-scute specifically expressed in neuronal precursors. Nature 346: 858-861.

Kengaku, M. and H. Okamoto. 1995. bFGF as a possible morphogen for the anteroposterior axis of the central nervous system in Xenopus. Development 121: 3121-3130.

Kintner, C.R. and J. Dodd. 1991. Hensen's node induces neural tissue in Xenopus ectoderm. Implications for the action of the organizer in neural induction. Development 113: 1495-1505.

Kintner, C.R. and D.A. Melton. 1987. Expression of Xenopus
N-CAM RNA in ectoderm is an early response to neural induction. Development 99: 311-325.

Lamb, T.M. and R.M. Harland. 1995. Fibroblast growth factor is a direct neural inducer, which combined with noggin generates anterior-posterior neural pattern. Development 121: $3627-3636$.

Lamb, T.M., A.K. Knecht, W.C. Smith, S.E. Stachel, A.N. Economides, N. Stahl, G.D. Yancopolous, and R.M. Harland. 1993. Neural induction by the secreted polypeptide noggin. Science 262: 713-718.

Launay, C., V. Fromentoux, D.L. Shi, and J.C. Boucaut. 1996. A truncated FGF receptor blocks neural induction by endog. enous Xenopus inducers. Development 122: $869-880$.

Lee, J.E., S.M. Hollenberg, L. Snider, D.L. Turner, N. Lipnick, and H. Weintraub. 1995. Conversion of Xenopus ectoderm into neurons by NeuroD, a basic helix-loop-helix protein. Science 268: 836-844.

Lin, Z.Y., C.A. Dechesne, J. Eldridge, and B.M. Paterson. 1989. An avian muscle factor related to MyoD1 activates musclespecific promoters in nonmuscle cells of different germ-layer origin and in BrdU-treated myoblasts. Genes \& Dev. 3: $986-$ 996.

Ma, Q., C. Kintner, and D.J. Anderson. 1996. Identification of neurogenin, a vertebrate neuronal determination gene. Cell 87: 43-52.

Maden, M. and N. Holder. 1992. Retinoic acid and development of the central nervous system. BioEssays 14: 431-438.

Mahmood, R., P. Kiefer, S. Guthrie, C. Dickson, and I. Mason. 1995. Multiple roles for FGF-3 during cranial neural development in the chicken. Development 121: 1399-1410.

New, D.A.T. 1955. A new technique for the cultivation of the chick embryo in vitro. J. Embryol. Exp. Morphol. 3: 326-331.

Nieuwkoop, P.D. 1952. Activation and organisation of the central nervous system in amphibians. III. Synthesis of a new working hypothesis. J. Exp. Zool. 120: 83-108.

Okamoto, H. and M. Kengaku. 1993. Basic fibroblast growth factor induces differentiation of neural tube and neural crest lineages of cultured ectoderm cells from Xenopus gastrula. Development 119: 1067-1078.

Piccolo, S., Y. Sasai, B. Lu, and E.M. De Robertis. 1996. Dorsoventral patterning in xenopus-Inhibition of ventral signals by direct binding of chordin to BMP-4. Cell 86: 589-598.

Riese, J., R. Zeller, and R. Dono. 1995. Nucleo-cytoplasmic translocation and secretion of fibroblast growth factor-2 during avian gastrulation. Mech. Dev. 49: 13-22.

Rubin, G.M. and A.C. Spradling. 1982. Genetic transformation of Drosophila with transposable element vectors. Science 218: 348-353.

Ruiz-Gómez, M. and J. Modolell. 1987. Deletion analysis of the achaete-scute locus of Drosophila melanogaster. Genes \& Dev. 1: 1238-1246.

Rupp, R.A., L. Snider, and H. Weintraub. 1994. Xenopus embryos regulate the nuclear localization of XMyoD. Genes \& Dev. 8: 1311-1323.

Sasai, Y., B. Lu, H. Steinbesser, and E.M. De Robertis. 1995. Regulation of neural induction by the Chd and Bmp-4 antagonistic patterning signals in Xenopus. Nature 376: 514-533.

Saxén, L. and S. Toivonen. 1961. The two gradient hypothesis in primary induction. The combined effect of two kinds of inductors mixed in different ratios. I. Embryol. Exp. Morphol. 9: 514-533.

Schoenwolf, G.C. 1992. Morphological and mapping studies of the paranodal and postnodal levels of the neural plate during chick neurulation. Anat. Rec. 233: 281-290.

Schoenwolf, G.C. and I.S. Alvarez. 1989. Roles of neuroepithelial cell rearrangement and division in shaping of the avian 
neural plate. Development 106: 427-439.

1991. Specification of neurepithelium and surface epithelium in avian transplantation chimeras. Development 112: 713-722.

Schoenwolf, G.C. and P. Sheard. 1990. Fate mapping the avian epiblast with focal injections of a fluorescent-histochemical marker: Ectodermal derivatives. J. Exp. Zool. 255: 323-339.

Sechrist, J. and M. Bronner-Fraser. 1991. Birth and differentiation of reticular neurons in the chick hindbrain-Ontogeny of the 1st neuronal population. Neuron 7: 947-963.

Selleck, M.A. and M. Bronner-Fraser. 1995. Origins of the avian neural crest: The role of neural plate-epidermal interactions. Development 121: 525-538.

Shawlot, W. and R.R. Behringer. 1995. Requirement for Lim1 in head-organizer function. Nature 374: 425-430.

Shimizu, C., C. Akazawa, S. Nakanishi, and R. Kageyama. 1995. MATH-2, a mammalian helix-loop-helix factor structurally related to the product of Drosophila proneural gene atonal, is specifically expressed in the nervous system. Eur. J. Biochem. 229: 239-248.

Shivdasani, R.A., E.L. Mayer, and S.H. Orkin. 1995. Absence of blood formation in mice lacking the T-cell leukaemia oncoprotein tal-1/SCL. Nature 373: 432-434.

Skeath, J.B. and S.B. Carroll. 1991. Regulation of achaete-scute gene-expression and sensory organ pattern-formation in the Drosophila wing. Genes \& Dev. 5: 984-995.

- 1994. The achaete-scute complex: Generation of cellular pattern and fate within the Drosophila nervous system. FASEB I. 8: 714-721.

Slack, J.M. and D. Tannahill. 1992. Mechanism of anteroposterior axis specification in vertebrates. Lessons from the amphibians. Development 114: 285-302.

Sommer, L., N. Shah, M. Rao, and D.J. Anderson. 1995. The cellular function of MASH1 in autonomic neurogenesis. Neuron 15: 1245-1258.

Spann, P., M. Ginsburg, Z. Rangini, A. Fainsod, H. Eyal-Giladi, and Y. Gruenbaum. 1994. The spatial and temporal dynamics of Sax 1 (CHox3) homeobox gene expression in the chick's spinal cord. Development 120: 1817-1828.

Spemann, H. 1927. Neue Arbeiten uber Organisatoren in der tierischen Entwicklung. Naturwissenschaften 15: 946-951.

Spemann, H. and H. Mangold. 1924. Uber Induktion von Embryoanlagen durch Implantation artfremder Organisatoren. Wilhelm Roux's Arch. Dev. Biol. 100: 599-638.

Spratt, N.T. 1952. Localisation of the prospective neural plate in early chick blastoderm. J. Exp. Zool. 120: 109-130.

Stern, C.D. 1990. The marginal zone and its contribution to the hypoblast and primitive streak of the chick embryo. Development 109: 667-682.

Storey, K.G., J.M. Crossley, E.M. De Robertis, W.E. Norris, and C.D. Stern. 1992. Neural induction and regionalisation in the chick embryo. Development 114: 729-741.

Storey, K.G., M.A. Selleck, and C.D. Stern. 1995. Neural induction and regionalisation by different subpopulations of cells in Hensen's node. Development 121: 417-428.

Streit, A., C.D. Stern, C. Thery, G.W. Ireland, S. Aparicio, M.J. Sharpe, and E. Gherardi. 1995. A role for HGF/SF in neural induction and its expression in Hensen's node during gastrulation. Development 121: 813-824.

Tsai, F.Y., G. Keller, F.C. Kuo, M. Weiss, J. Chen, M. Rosenblatt, F.W. Alt, and S.H. Orkin. 1994. An early haematopoietic defect in mice lacking the transcription factor GATA-2. $\mathrm{Na}$ ture 371: 221-226.

Turner, D.L. and H. Weintraub. 1994. Expression of achaetescute homolog 3 in Xenopus embryos converts ectodermal cells to a neural fate. Genes \& Dev. 8: 1434-1437.
Villares, R. and C.V. Cabrera. 1987. The achaete-scute gene complex of $D$. melanogaster: Conserved domains in a subset of genes required for neurogenesis and their homology to myc. Cell 50: 415-424.

Waddington, C.H. 1932. Experiments on the development of chick and duck embryos cultivated in vitro. Phil. Trans. $R$. Soc. Lon. B221: 179-230.

Weintraub, H. 1993. The MyoD family and myogenesis: Redundancy, networks, and thresholds. Cell 75: 1241-1244.

Zimmerman, K., J. Shih, J. Bars, A. Collazo, and D.J. Anderson. 1993. XASH-3, a novel Xenopus achaete-scute homolog, provides an early marker of planar neural induction and position along the mediolateral axis of the neural plate. Development 119: $221-232$.

Zimmerman, L.B., J.M. De Jesus-Escobar, and R.M. Harland. 1996. The Spemann organizer signal noggin binds and inactivates bone morphogenetic protein-4. Cell 86: 599-606. 


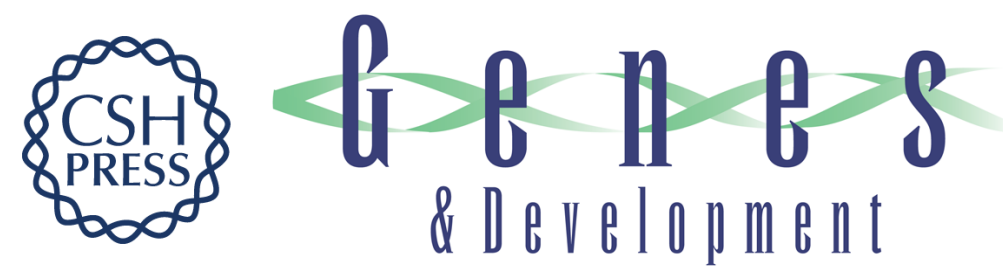

\section{cash4, a novel achaete-scute homolog induced by Hensen's node during generation of the posterior nervous system.}

D Henrique, D Tyler, C Kintner, et al.

Genes Dev. 1997, 11:

Access the most recent version at doi:10.1101/gad.11.5.603

$\begin{array}{ll}\text { References } & \begin{array}{l}\text { This article cites } 79 \text { articles, } 31 \text { of which can be accessed free at: } \\ \text { http://genesdev.cshlp.org/content/11/5/603.full.html\#ref-list-1 }\end{array}\end{array}$

License

Email Alerting Receive free email alerts when new articles cite this article - sign up in the box at the top Service right corner of the article or click here.

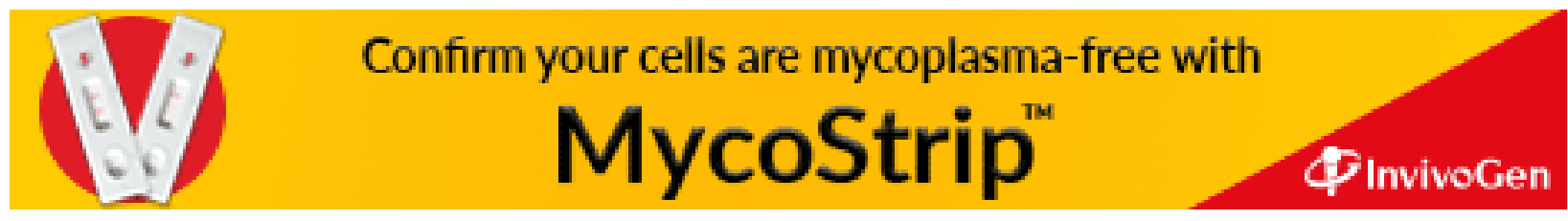

